\title{
Svak kobling mellom kronisk utmattelsessyndrom og pyruvat dehydrogenasemangel
}

DEBATT

YNGVE THOMAS BLIKSRUD

E-post:ybliksru@ous-hf.no

Yngve Thomas Bliksrud er overlege og ph.d. ved Oslo universitetssykehus, Rikshospitalet. Forfatter har fylt ut ICMJE-skjemaet og oppgir følgende interessekonflikter: Han har mottatt honorar for et foredrag i et faglig forum av psykiatere som var støttet av det farmasøytiske selskapet Lundbeck Norge.

I en studie av energimetabolismen hos pasienter med kronisk utmattelsessyndrom konkluderer forskerne med redusert pyruvat dehydrogenaseaktivitet hos pasientene, men målingene stemmer ikke med endringene vi ser hos pasienter med primær genetisk pyruvat dehydrogenasemangel.

I en tverrsnittsstudie publisert i desember 2016 ble det funnet endret mønster av aminosyrer i plasma hos pasienter med kronisk utmattelsessyndrom. I tillegg ble det påvist endret genuttrykk i hvite blodceller og endret energiomsetning i muskelceller (1). Forfatterne tolker resultatene som uttrykk for funksjonell hemming av enzymet pyruvat dehydrogenase, og de foreslår dysregulering av enzymkomplekset som en mulig nøkkelfaktor i patogenesen ved kronisk utmattelsessyndrom.

Studien fikk omfattende mediedekning $(2,3)$, og koblingen til pyruvat dehydrogenase slås fast i offentligheten uten forbehold $(4,5)$. Ved vårt laboratorium mottar vi nå prøver til metabolsk screening fra pasienter med mulig utmattelsessyndrom. Basert på min erfaring med biokjemisk diagnostikk av pyruvat dehydrogenasemangel vil jeg påpeke svakheter $\mathrm{i}$ studien som burde ansporet til betydelig større grad av forsiktighet i konklusjonene.

\section{Kritikk av metode og fortolkning}

I studien ble aminosyrekonsentrasjonene i plasma fra 200 pasienter og 102 friske kontrollpersoner unders $ø$ kt. Forskerne fant signifikante forskjeller mellom de to gruppene, men betydningen er uklar fordi de ikke har forholdt seg til etablert diagnostikk ved pyruvat dehydrogenasemangel, og fordi prøvene ikke er tatt på en standardisert måte.

\section{AMINOSYREMØNSTERET STEMMER IKKE MED DET VI SER HOS PASIENTENE MED PRIMAER PYRUVAT DEHYDROGENASEMANGEL}

Pyruvat dehydrogenasemangel gir $ø$ kt konsentrasjon av pyruvat i for eksempel muskel- og nerveceller. Pyruvat omdannes til laktat og aminosyren alanin. Alanin er den eneste aminosyren som forventes å være utenfor referanseintervallet i plasma og spinalvæske ved 
primær pyruvat dehydrogenasemangel (halvannen til to ganger øvre referansegrense) (6). I studien rapporteres imidlertid en tendens til lavere alaninnivåer hos pasientene. Det er overraskende at denne slående diskrepansen ikke er omtalt i artikkelen.

MANGLENDE STANDARDISERING VED PRøVETAKING KAN FORKLARE FORSKJELLEN MELLOM GRUPPENE

Fastende prøve er sterkt anbefalt ved bestemmelse av plasmakonsentrasjonen av aminosyrer, fordi nivåene varierer betydelig med kosten og dessuten naturlig gjennom døgnet med opptil 10-15\% (6). I studien sammenlignes ikke-fastende aminosyremønstre med små avvik, ned til $3 \%$ tillegges betydning.

Det er svært underlig at ikke forfatterne tar større forbehold om diett som konfunderende faktor, når de selv har påvist at kosten påvirker nettopp den gruppen aminosyrer som utgjør argumentet for svekket pyruvat dehydrogenase.

I studien ble det påvist signifikante forskjeller mellom fastende og ikke-fastende pasienter. De fastende pasientene ble derfor ekskludert i det videre statistiske arbeidet. Da burde forfatterne også tatt tydeligere forbehold om at en eventuell skjult skjevhet mellom pasientgruppen og kontrollgruppen med hensyn til diett og prøvetaking kan være en alternativ forklaring til flere av forskjellene de fant. Systematiske forskjeller i diett mellom gruppene er ikke utenkelig.

Gastrointestinale symptomer (magesmerter, kvalme, irritert tarm m.m.) inngår i konsensuskriteriene for diagnosen (7). Spesielle diettvaner ved kronisk utmattelsessyndrom har vært rapportert tidligere (8).

HVA MED PYRUVAT/LAKTAT-RATIO OG DIREKTE MÅLING AV PYRUVAT DEHYDROGENASEAKTIVITET?

Pyruvat/laktat-ratio i plasma kan skille pasienter med pyruvat dehydrogenasemangel fra andre pasienter med hyperlaktacidemi. Ratioen har derfor en sentral plass ved biokjemisk diagnostikk av pyruvat dehydrogenasemangel (9).

I studien er pyruvat/laktat-ratio ikke bestemt. Det er synd, ratioen kunne gitt et viktig holdepunkt for, eventuelt mot, pyruvat dehydrogenasemangel. Direkte bestemmelse av enzymaktiviteten i celler er også sentralt ved rutinediagnostikk av pyruvat dehydrogenasemangel. Det er underlig at dette ikke er gjort i studien av muskelceller som vokser i nærvær av pasientserum.

SPESIFIKK KOBLING TIL KRONISK UTMATTELSESSYNDROM KREVER FLERE KONTROLLGRUPPER

I studien har pasientgruppen et annet ekspresjonsmønster enn kontrollgruppen med hensyn til gener knyttet til pyruvat dehydrogenasekompleks. Det er et interessant resultat, men studien gir ikke grunnlag for å tolke forskjellen som spesifikk for kronisk utmattelsessyndrom.

Ifølge konsensuskriteriene har pasientene hatt et «substansielt redusert aktivitetsnivå» i en varighet på «minimum et halvt år» (7). Det er velkjent at ekspresjonen av gener knyttet til hele energistoffskiftet (inkludert pyruvat dehydrogenasekompleks) endres ved immobilisering (10). Muskulatur vokser og svinner med aktivitetsnivået, ulike ekspresjonsmønstre er følgelig rett og slett å forvente mellom de to gruppene i denne studien. Før ekspresjonsmønsteret eventuelt kan knyttes spesifikt til kronisk utmattelsessyndrom må de ikke bare sammenlignes med friske, men med andre pasientgrupper som opplever et tilsvarende redusert aktivitetsnivå, for eksempel pasienter med hjerneslag, bruddskader, nyresvikt eller alvorlige depresjoner.

I studien er det også vist at muskelceller in vitro får endret energimetabolisme i nærvær av serum fra pasienter med kronisk utmattelsessyndrom. Det er interessant at dette lar seg påvise eksperimentelt, men heller ikke denne observasjonen kan uten videre knyttes spesifikt til kronisk utmattelsessyndrom. Også her trengs flere kontrollgrupper av pasienter 
med redusert aktivitetsnivå av andre årsaker. Studien viser for eksempel redusert produksjon av høyenergifosfater (ATP) in vitro. I en musemodell hvor muskelceller dyrkes i nærvær av serum fra individer med muskelatrofi og kronisk nyresvikt, blir også ATPproduksjon redusert (11).

KRONISK UTMATTELSE ER IKKE TYPISK FOR PRIMAR GENETISK PYRUVAT DEHYDROGENASEMANGEL

Forfatterne foreslår pyruvat dehydrogenasemangel som en nøkkel i patofysiologien ved kronisk utmattelsessyndrom. Kronisk utmattelse er ikke et typisk symptom hos pasienter med primær genetisk pyruvat dehydrogenasemangel, verken alvorlig eller mild form (9). Det krever en kommentar, men er ikke nevnt med et ord.

\section{Nøkterne vurderinger etterlyses}

Forskning på metabolske mekanismer ved kronisk utmattelsessyndrom er interessant, og Fluges og medarbeideres store arbeid kan generere hypoteser som det er vel verd å undersøke videre. Men forfatterne har vært utilbørlig tidlig ute med nærmest å slå fast pyruvat dehydrogenasemangel som en del av patofysiologien bak kronisk utmattelsessyndrom. Foreløpig er koblingen mellom påviste aminosyreendringer og pyruvat dehydrogenasemangel for svak, og endringen i genekspresjon og energimetabolisme for uspesifikk til en så bastant konklusjon.

\section{LITTERATUR:}

1. Fluge $\emptyset$, Mella $O$, Bruland $O$ et al. Metabolic profiling indicates impaired pyruvate dehydrogenase function in myalgic encephalopathy/chronic fatigue syndrome. JCI Insight 2016; 1: e89376. [PubMed][CrossRef]

2. Pedersen K. Bergens Tidende 1.1.2017. UiB-forskning: ME-syke har defekt i energistoffskiftet. https://www.bt.no/nyheter/lokalt/i/8M2rQ/UiB-forskning-ME-syke-har-defekt-ienergistoffskiftet (15.11.2017).

3. TV2. Nyhetene 8.1.2017. https://www.youtube.com/watch?vFokQZ8jc5WM (15.11.2017).

4. Universitetet i Bergen. Mennesker som lider av kronisk utmattelse har defekt i stoffskiftet. 2.1.2017. http://www.uib.no/biomedisin/103853/mennesker-som-lider-av-kronisk-utmattelse-har-defekt-i-stoffsk iftet (15.11.2017).

5. Fluge $\emptyset$, Mella O, Tronstad KJ. Ny studie om PDH-enzymet og ME fra forskningsgruppen i Bergen. Kavlifondet.

https://kavlifondet.no/2016/12/ny-studie-om-sykdomsmekanismer-ved-me-fra-forskningsgruppen-i-ber gen/ (15.11.2017).

6. Pasquali M, Longo N. Amino Acids I: Blau N, Duran M, Gibson KM et al, red. Physician's guide to the diagnosis, treatment, and follow-up of inherited metabolic diseases. Berlin: Springer, 2014: 749-59.

7. Carruthers BM, Jain AK, De Meirleir KL et al. Myalgic encephalomyelitis/ chronic fatigue syndrome: clinical working case definition, diagnostic and treatment protocols. J Chronic Fatigue Syndr 2003; 11: 7 -115. [CrossRef]

8. Fisher M, Krilov LR, Ovadia M. Chronic fatigue syndrome and eating disorders: concurrence or coincidence? Int J Adolesc Med Health 2002; 14:307 - 16. [PubMed][CrossRef]

9. De Meirleir LJ, Garzia-Cazorla A, Brivet M. Disorders of pyruvate metabolism and the tricarboxylic acid cycle. I: Saudubray JM, Baumgartner MR, Walter J, red. Inborn metabolic diseases, diagnosis and treatment. 6. utg. Berlin: Springer, 2016:187-99.

10. Abadi A, Glover EI, Isfort RJ et al. Limb immobilization induces a coordinate down-regulation of mitochondrial and other metabolic pathways in men and women. PLoS One 2009; 4: e6518.

[PubMed][CrossRef]

11. Su Z, Klein JD, Du J et al. Chronic kidney disease induces autophagy leading to dysfunction of 
mitochondria in skeletal muscle. Am J Physiol Renal Physiol 2017; 312: F1128 - 40. [PubMed][CrossRef]

Publisert: 28. november 2017. Tidsskr Nor Legeforen. DOI: 10.4045/tidsskr.17.0948

Mottatt 1.11.2017, første revisjon innsendt 15.11.2017, godkjent 17.11.2017.

(C) Tidsskrift for Den norske legeforening 2020. Lastet ned fra tidsskriftet.no 